DOI: 10.17746/1563-0110.2019.47.3.074-084

\author{
A.M. Murygin ${ }^{1}$, P.A. Kosintsev ${ }^{2,3}$, and T.I. Marchenko-Vagapova ${ }^{4}$ \\ ${ }^{1}$ Institute of Language, Literature, and History, \\ Komi Research Center, Ural Branch, Russian Academy of Sciences, \\ Kommunisticheskaya 26, Syktyvkar, 167982, GSP-2, Russia \\ E-mail: alek-murygin@yandex.ru \\ ${ }^{2}$ Ural Federal University, \\ Pr. Lenina 51, Yekaterinburg, 620002, Russia \\ ${ }^{3}$ Institute of Plant and Animal Ecology, \\ Ural Branch, Russian Academy of Sciences, \\ 8 Marta 202, Yekaterinburg, 620144, Russia \\ E-mail:kpa@ipae.uran.ru \\ ${ }^{4}$ Institute of Geology, Komi Research Center, \\ Ural Branch, Russian Academy of Sciences, \\ Pervomaiskaya 54, Syktyvkar, 167982, Russia \\ E-mail: timarchenko@geo.komisc.ru
}

\title{
An Early Iron Age Camp of Reindeer Hunters in the Bolshezemelskaya Tundra, Nenets Autonomous Okrug
}

This study outlines the findings of excavations at More-Yu II-a site in the northern Bolshezemelskaya tundra. The habitation-layer, with numerous charcoal lenses, was discovered inside the layer of buried soil, which was overlaid by eolian sand. Most of the finds are ceramics and animal bones; arrowheads, adornments, tools, and ritual items are very rare. On the basis of palynological and faunal analyses, environmental changes from the time of Subboreal warming until the end of the Subatlantic period are reconstructed. The temperature regime during the formation of cultural deposits was unstable. The principal subsistence strategy was reindeer hunting. The age distribution of the hunted reindeer suggests that habitation periods coincided with cold seasons. Radiocarbon dates generated from reindeer bones point to the Early Iron Age. The camp dwellers were native reindeer hunters inhabiting the tundra belt of northeasternmost Europe. Ceramics representing the More-Yu type belong to the early stage of the Subarctic Pechora culture. They mark the Arctic component that became part of the northern Glyadenovo population, abruptly changing the Finno-Permic culture of the taiga part of the Pechora basin in Cis-Urals.

Keywords: Northeastern Europe, Early Iron Age, settlement, reindeer.

\section{Introduction}

The circumpolar zone of northeastern Europe is among the Russian regions with insignificantly studied archaeological records: archaeological works in this region are only carried out occasionally.
The source of information on Iron Age archaeology in the northeasternmost tundra area of Europe includes the finds from not more than 20 archaeological sites where excavations of culture-bearing strata were carried out. These sites, of varying degrees of examination, have yielded archaeological materials attributable to a wide

Archaeology, Ethnology \& Anthropology of Eurasia 47/3 (2019) 74-84 E-mail: Eurasia@archaeology.nsc.ru (C) 2019 Siberian Branch of the Russian Academy of Sciences

(c) 2019 Institute of Archaeology and Ethnography of the Siberian Branch of the Russian Academy of Sciences (C) 2019 A.M. Murygin, P.A. Kosintsev, T.I. Marchenko-Vagapova 
chronological range between the second half of the 1 st to the first half of the 2nd millennia AD. The majority of the finds are ceramics; hence, it is rather difficult to determine the chronological range of the identified cultural types and separate complexes. The materials from the site of More$\mathrm{Yu}$ II in the Bolshezemelskaya tundra deserve special attention, because the excavation data provide a basis for more accurate determination of the age of sites located in high latitudes.

\section{Description of the site}

The site of More-Yu II is located in the north of the Bolshezemelskaya tundra, at a distance of about $60 \mathrm{~km}$ from the southeastern coast of the Barents Sea. This is a region of relic spruce-fir-birch sparse forest on the $30 \mathrm{~m}$ promontory (which is bounded by hollows) on the right-side bank of the More-Yu River (Fig. 1). In 1967 , some artifacts were collected from the surface of the blown-out depressions where the More-Yu site was located (Kanivets, 1967: 18; Murygin, 1990). The area of surface finds was excavated in 1987-1988 and 1991. The research data of 1987-1988 were partially described (Murygin, 1992: 68-75, fig. 30-32). In 2007, the site was examined by the archaeologists from the Arkhangelsk Regional Studies Museum (Edovin, 2007).

The top soil of the bank is subjected to soil-blowing. The excavation area of about $1014 \mathrm{~m}^{2}$ was established on the intact surface, 150-200 $\mathrm{m}$ from the edge of the terrace (Fig. 2). Within the study-area, cultural remains were found below the eolian sand layer, which was up to $170 \mathrm{~cm}$ thick. The cultural remains were embedded in the layer of buried soil up to $12 \mathrm{~cm}$ thick. The finds, including fragmented vessels, potsherd accumulations, and faunal remains, were concentrated mostly around fireplaces.

Within the excavated culture-bearing layer, two types of archaeological items of anthropogenic origin were recorded.

1. Fireplaces (Fig. 2). In total, ten ash and charcoal lenses were uncovered. The lenses are filled mainly with fragments of pottery, and animal bones. Two fireplaces had been destroyed by blow-outs (I and IX). Those that were preserved are subdivided into two groups. The first group (III, IV, XIII, and X) includes spots of dense black concentrations of ash and charcoal, sub-rectangular

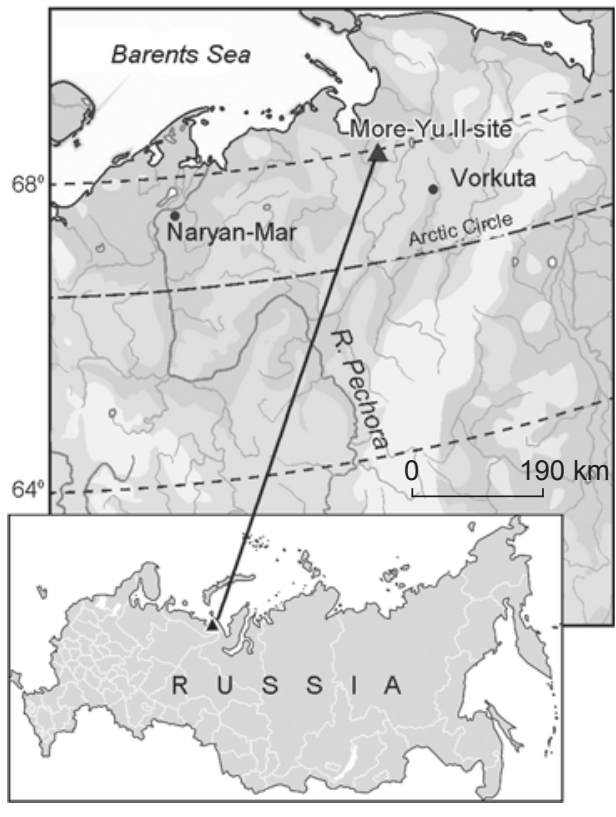

Fig. 1. Location of the More-Yu II site.

Fig. 2. Map showing locations of the excavation areas of More-Yu II.

1 - border of the steep blow-out gully; 2 - remains of the culture-bearing layer in gully; 3 - preserved fireplaces; 4 - destroyed fireplaces; 5 - animal bone accumulations; 6 - bushes. Fireplaces are marked with Roman numerals; bone-accumulations with Arabic numerals.

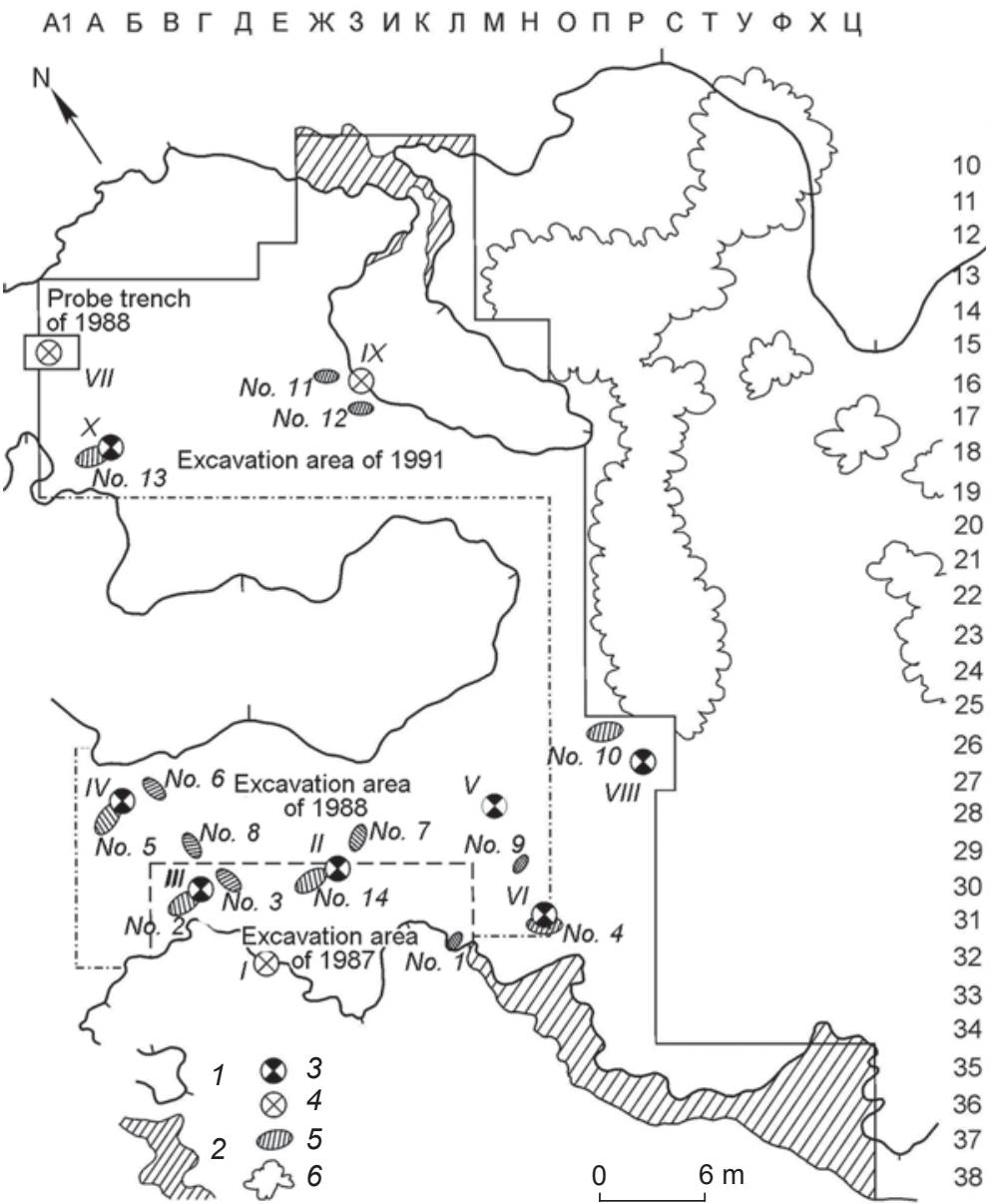


in shape, with clear boundaries with surrounding sandy deposits. The second group (II, V-VII) includes amorphous spots of loose, grayish-brown concentrations of ash and charcoal, without clear boundaries with sand deposits. Fireplaces II and VIII each showed a lens of caked sand.

2. Spots of humic sand (Fig. 2). Thirteen areas of brown sand, varying in shape and size, were identified. These commonly contained raw animal bones and ceramic fragments. The areas differed in their proportions of ceramic and bone materials. In humic spots 2,4 , and 5 , the proportion of bones was significant, while that of ceramic fragments was minor. Humic spots 1, 3, 6, 7, 10-13 contained a lot of ceramic fragments, including fragmented vessels, while raw bones were few. The greatest concentration of raw animal bones (No. 14), overlying a thin charcoal lens, was uncovered next to the edge of fireplace II (Fig. 2). Below the bone concentration, a large broken vessel was found.

Within the excavation area, a sub-rectangular depression $(6.3 \times 3.3-3.6 \mathrm{~m})$ was found (Murygin, 1992: Fig. 31, 32, prof. III). It revealed a spotty concentration of mixed sands. The depression might have been man-made or have been formed naturally by the water flowing down the slope of the terrace.

\section{Artifact inventory}

Arrowheads. These were made of iron. The first arrowhead is faceted, tanged, and awl-shaped, with a squared cross-section and an ordinary stopper (Fig. 3, 9). It is similar to the arrowheads of type 90, which emerged at the beginning of our era and survived till the 14th century (Medvedev, 1966: 59, pl. 30, D, 82). The arrowhead was found in the humic spot 5 . The second arrowhead is flat, tanged, and elongated-triangular (Fig. 3, 13). Judging by the West Siberian archaeological materials, such arrowheads were used starting from the late 1st millennium $\mathrm{AD}$ till the ethnographically modern period (Soloviev, 1987: Pl. III, 24, 25). This arrowhead was found in fireplace VI. The third arrowhead is flat, tanged, with two barbs and without a stopper (Fig. 3, 12). It is similar to the arrowheads of type 29, which were used between the 1 st century BC and the 14th century AD (Medvedev, 1966: 44, pl. 18, 10). It was found in fireplace VI. The fourth arrowhead is wedge-shaped, with a flat tang (Fig. 3,11). Its blades are convex, the shoulders concave, smoothly turning into the tang; low crests are visible on both surfaces of the arrowhead. This arrowhead was found in fireplace III.

Tools. The first tool is an abrader or a stone (schist) burnisher (Fig. 3, 18). It was found in humic spot 5 . The second tool is a trapezoidal bone "spatula" with an archshaped top and a straight base (Fig. 3, 17). Its flat surface is ground; the opposing long sides show cut scars. The piece was found in humic spot 13 .

Adornments. The first adornment is a glazed faience (?) bead, ribbed-rounded, turquoise blue, trapezoidal in cross-section (Fig. 3, 1). It shows parallels with similar adornments from the northern Black Sea region (Alekseeva, 1975: Pl. 5, 30). Similar beads made of Egyptian faience belong to type 16d; these were found mostly in the burials of the 1st-2nd centuries $\mathrm{AD}$, with some pieces belonging to the 1 st century $\mathrm{BC}$, and to the 3rd-4th centuries AD (Ibid.: 34). A similar bead found in the Bichevnik I settlement in the Middle Pechora was attributed to the artifact set of the first half to the middle of the 1st millenium AD (Turkina, 2015: 83, fig. 5, 6). The bead was found in square $H / 26$. The second adornment is a yellowish glass bead fragment (Fig. 3, 2), found in fireplace VIII. The third is a fragment of a yellow glass bead (Fig. 3, 3), found in fireplace IV. The fourth and fifth are two small, bi-trapezoidal bronze beads (Fig. 3, 4,5 ), found in fireplace IV. The sixth piece in this set is a fragment of a tubular bead (Fig. 3, 6); remains of the "ears" and concentric decoration in the form of two relief bands are visible on its exterior surface. The item was found in fireplace VIII. The seventh adornment is a bronze pendant (Fig. 3, 7). Its base is round, openwork, in the form of several wire rings soldered one into another, with a soldered hanging loop at the top. The piece was found in square $\mathrm{M} / 15$.

Ritual items. The first one is a bronze zoomorphic ritual item (Fig. 3, 8). It is an unfinished cast with a short sprue at its base. It was found in humic spot 5 . Similar items have been reported from ritual features in the Kheibidya-Pedar sanctuary (Murygin, 1992: Fig. 14; 15, 16-22) and the sanctuaries of Bolvanski Nos I (Khlobystin, 1993: Fig. 1, 32) and Sirtya-Sale (Khlobystin, 1991: 31-32, fig. 10, 11, 13; Baryshev, 2011: Fig. 42, 4-7). The second item is an amulet (?) of a bear canine tooth (Fig. 3, 16). It shows signs of treatment and a few notches. The item was found in square $\mathrm{C} / 27$. The culture-bearing layer also yielded 48 indefinable iron fragments, 5 drops of non-ferrous metal, a stone tablet with use-wear signs, two bone fragments with usewear signs, and 21 pieces of slag.

Among surface artifacts from the disturbed fireplace I (see Fig. 2), there were an iron awl (see Fig. 3, 15) and a defective (?) cast or a blank of a thick bronze arrowhead with a non-projecting, interior socket, blades, and a small hole close to the pointed tip (see Fig. 3, 14). The last-named item is comparable to bronze arrowheads of type XIII, which were used by the Sarmatian tribes of the Volga and Cis-Ural regions in the 4th to 2nd centuries BC (Ivanov, 1984: 7-9, fig. 2, 23, 24, 26, 27). Surface artifacts from the disturbed fireplace IX (see Fig. 2) contain a fragment of a bronze three-bladed arrowhead (see Fig. 3, 10). 


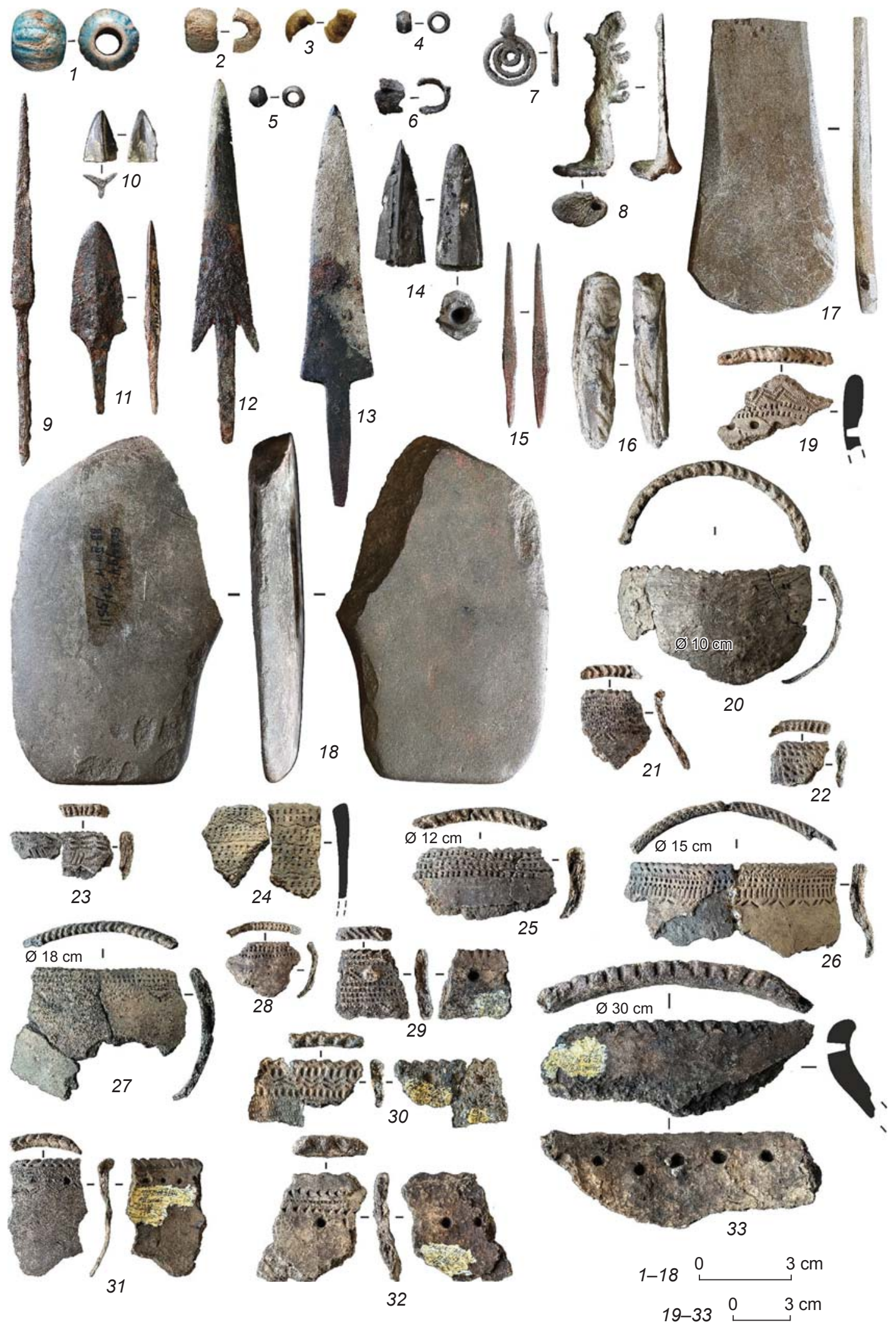

Fig. 3. Artifacts from More-Yu II.

1-5 - beads; 6 - tubular bead; 7 - pendant; 8 - cult item; 9-14 - arrowheads; 15 - awl; 16 - animal's canine tooth (amulet?); 17 - "spatula"; 18 - burnisher (?); 19-33 - vessel fragments: 19 - group VII, 20 - I, 21-28 - II, 29-33 - III. 1-3 - glass; 4-8, 10, 14 - bronze; 9, 11-13, 15 - iron; 16,17 - bone; 18 - stone; 19-33-ceramics. 
Ceramics. The total collection of ceramic fragments includes 10,272 specimens. On the basis of the ornamented fragments, not less than 126 vessels were identified* (Fig. 3, 19-33; 4). The potsherds were classified into seven formal-typological groups by their features of ornamental motifs, the locations of ornaments in the upper parts of the bodies of vessels, and the peculiarities of vessels' shapes. In terms of planigraphy, none of the groups stands out in the excavation area.

Group I (2 spec., see Fig. 3, 20). Vessels show ornaments only on the rims. Group II (10 spec.; see Fig. 3, 21-28). Outer surfaces of vessel-bodies do not show pits as ornamental elements. Group III (5 spec.; see Fig. 3, 29-33). The special feature of ornamentation is the presence of pits inside vessels. Group IV (4 spec.; Fig. 4, 1,2). Vessels are decorated only on the outside, with horizontal lines of pits at the base of the neck. Group $\boldsymbol{V}$ (81 spec.). Vessels are subdivided into two varieties on the basis of the location of ornament. Variety V.1 (Fig. 4, $3-6)$. Ornament is located only on the neck, above the line of pits, under the rim. Variety V.2 (Fig. 4, 7-23, 26-33). Ornament is located on the shoulders and necks of vessels. Group VI (7 spec.; Fig. 4, 24, 25). The vessels differ from those of Group V in the form of their upper portion (evenly thick, and a straight or everted neck), while their elements and patterns of ornament are similar. Group VII is represented by only one vessel with a characteristic protrusion on the rim (see Fig. 3, 19).

Quite few vessels were reconstructed (fully or partially). These include closed bowls with narrowed mouths and without necks; a bowl-shaped vessel with a narrowed mouth, a nearly globe-shaped body, and a short, evenly thick and everted neck; and semi-ovoid vessels with pointed bottoms and thickened necks. The ceramic collection is dominated by fragments illustrating the shape of the upper portions of the vessels. The vessels with thickened necks prevail (58.2\%). Vessels with another shape of the upper part are rare: without neck $-19.1 \%$ (or and straight-walled bowls); with everted necks $-14.5 \%$; with straight or inclined necks $8.2 \%$. Rim diameters were established in 50 vessels: 8-10 cm - 3 spec., $12-18 \mathrm{~cm}-10$ spec., $20-29 \mathrm{~cm}-$ 16 spec., and $30-40 \mathrm{~cm}-21 \mathrm{spec}$. All the vessels are hand-made. The clay is dominated by admixture of grus with varying grain-size. One vessel was made of clay with an admixture of grog (?) (see Fig. 4, 3). No less than 36 vessels show traces of smoothing through combing on the interior and/or exterior surfaces; soot deposits were noted on 22 vessels.

Vessel rims are as follows: rounded (43 spec., $39.1 \%$ ); flattened, beveled inside (48 spec., $43.6 \%$ ) and beveled outside ( 2 spec., $1.8 \%$ ); horizontally cut (9 spec.; $8.2 \%$ );

\footnotetext{
*The total of 110 specimens with the best-preserved ornamented zones have been recorded.
}

and flattened and rounded (8 spec.; $7.3 \%$ ). Ornaments were made with a cogged stamp $(82.7 \%)$, oblique or upright $(12.7 \%)$ stamp; or in the form of chevron or arch $(70.0 \%)$. The rims were often decorated with deep incisions, resulting in a "serrated" surface; the incisions invaded the interior or exterior neck surfaces close to the edge. Finger impressions were noted on $17.3 \%$ of all the ceramics.

Closed bowls with unprofiled edges and bowlshaped vessels with profiled edges of group $\mathrm{V}$ are most numerous in the collection ( $73.6 \%$, see Fig. 4, 3-23, 26-33). The main features of these vessels are: 1) thickened, straight, or slightly folded inward, short neck; 2) mineral admixture in the clay; 3 ) deep pits at the neck base on the outside; 4) horizontal cannelures; 5) cogged stamp imprints; 6) the ornamentation zone is located on the upper part of vessel; the richly decorated specimens show dense concentrations of various motifs; 7) overand under-framing of the ornamentation zone with zigzag motifs; multi-zone ornamentation of neck with various motifs; location of motifs between and inside cannelures; 8) ornament patterns include combinations of deep pits, grooves-cannelures, cogged stamp imprints (including two-cogged oval and straight); along with lines of vertical and oblique imprints and zigzag, there are horizontal imprints and zigzag with one doubled side and with prominent ends, resembling horizontal S- and Z-shaped motifs; 9) pit-comb-cannelure ornamentation style.

Vessels of groups V and VI (6.4 \%; see Fig. 4, 24, 25) share certain characteristic features; the two groups make $80 \%$ of the total number of ceramics, and determine the ethnic-cultural specificity of the site. It does not seem to be a great mistake to attribute also vessels of groups I, II, and IV (see Fig. 3, 20-28; 4, 1, 2) to this definitive collection.

\section{Discussion of the materials}

Analysis of the archaeological materials of the 1st millennium AD from the tundra zone of the Pechora basin in Cis-Urals attests to their cultural homogeneity within the framework of the high-latitude archaeological culture of the Subarctic type (Murygin, 1992). The area of this culture distribution is bounded by the Subarctic Pechora zone in the west and the Yamal tundra in the east, where the late types of ceramics show a certain similarity with the Tiutei-Sale pottery.

On the basis of the More-Yu II materials, the More-Yu cultural type was identified as a stage of the Subarctic Iron Age culture; the time of this stage was initially attributed to the mid-1st millennium $\mathrm{AD}$, and subsequently to the late 4th to 6th centuries AD (Murygin, 1992: 163; 1997: Fig. 18). The results of the radiocarbon dating of bone- 


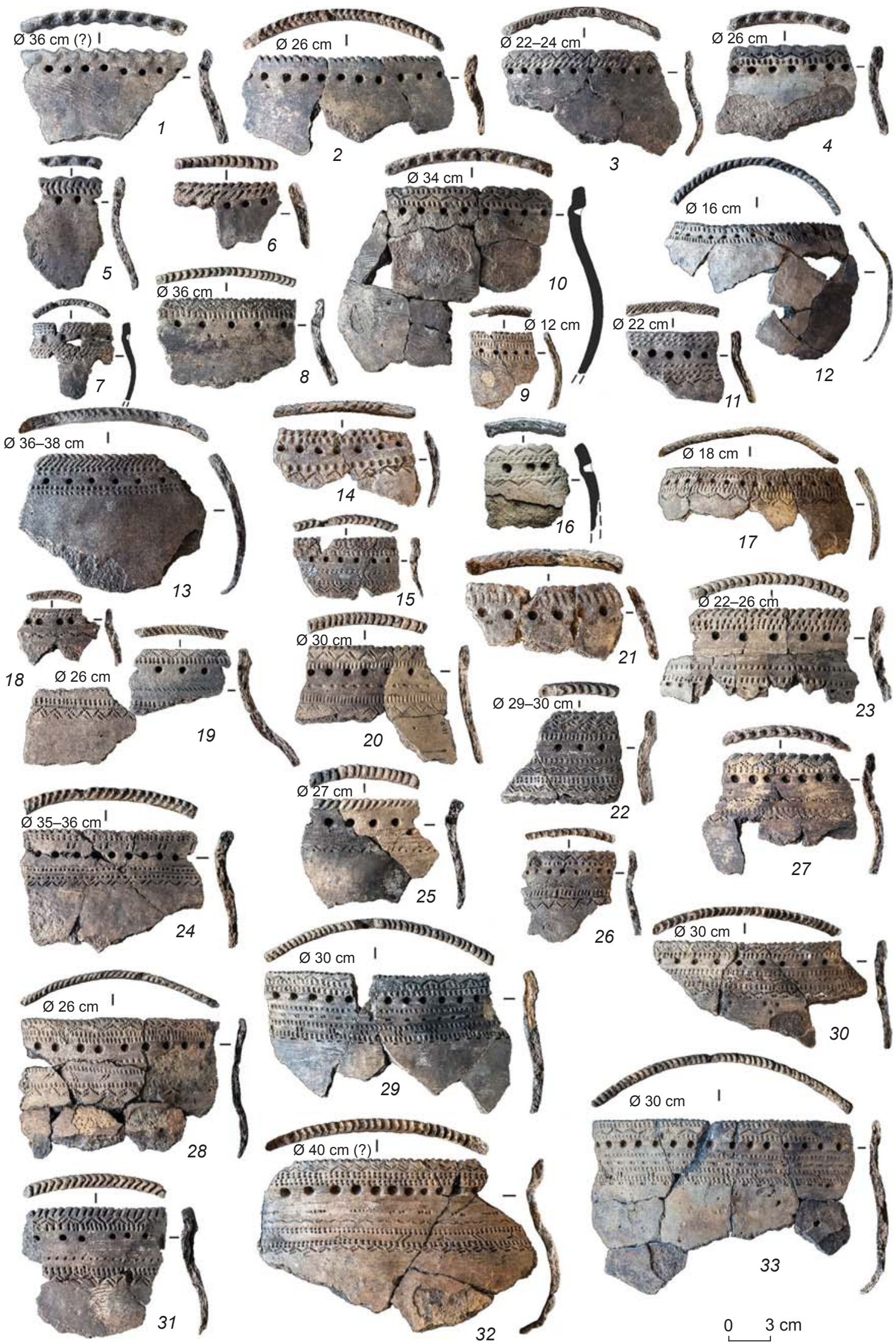

Fig. 4. Vessel-fragments from More-Yu II. 1, 2 - group IV; 3-23, 26-33-V; 24, 25 - VI. 
Radiocarbon dates obtained from reindeer bones from More-Yu II (studies of 1987-1988 and 1991)

\begin{tabular}{|c|c|c|c|c|}
\hline \multirow{2}{*}{$\begin{array}{l}\text { Sample } \\
\text { No. }\end{array}$} & \multirow{2}{*}{ Lab code } & \multirow{2}{*}{$\begin{array}{l}{ }^{14} \mathrm{C} \text {-date, yrs } \\
\text { BP }\end{array}$} & \multicolumn{2}{|c|}{ Calendar date } \\
\hline & & & $\pm 1 \sigma(68.2 \%)$ & $\pm 2 \sigma(95.4 \%)$ \\
\hline 1 & SPb-1059 & $1950 \pm 50$ & $\begin{array}{c}18(1.2 \%)-15 \mathrm{cal} \mathrm{BC} \\
1(56.7 \%)-90 \mathrm{cal} A D \\
100(10.2 \%)-123 \mathrm{cal} A D\end{array}$ & $\begin{array}{c}54 \mathrm{cal} \mathrm{BC}(94.2 \%)-172 \mathrm{cal} A D \\
193(1.2 \%)-210 \mathrm{cal} \mathrm{AD}\end{array}$ \\
\hline 2 & SPb-1447 & $2227 \pm 75$ & $\begin{array}{l}381(16.1 \%)-341 \mathrm{cal} \mathrm{BC} \\
328(52.1 \%)-204 \mathrm{cal} \mathrm{BC}\end{array}$ & $\begin{array}{c}408(94.3 \%)-89 \mathrm{cal} \mathrm{BC} \\
75(1.1 \%)-58 \mathrm{cal} \mathrm{BC}\end{array}$ \\
\hline 3 & $\mathrm{SPb}-2804$ & $1240 \pm 25$ & $\begin{array}{c}690(47.0 \%)-749 \mathrm{cal} \text { AD } \\
761(12.4 \%)-777 \mathrm{cal} \mathrm{AD} \\
793(4.5 \%)-802 \mathrm{cal} A D \\
845(4.4 \%)-855 \mathrm{cal} \text { AD }\end{array}$ & $\begin{array}{l}685(65.5 \%)-780 \text { cal AD } \\
788(29.9 \%)-875 \text { cal AD }\end{array}$ \\
\hline 4 & SPb-2805 & $2012 \pm 35$ & $\begin{array}{c}48 \text { cal BC }(65.7 \%)-\text { cal AD } \\
43(2.5 \%)-47 \text { cal AD }\end{array}$ & $109 \mathrm{cal} \mathrm{BC}(95.4 \%)-70 \mathrm{cal} A D$ \\
\hline 5 & SPb-2806 & $2447 \pm 35$ & $\begin{array}{c}743(20.9 \%)-687 \mathrm{cal} \mathrm{BC} \\
665(7.0 \%)-645 \mathrm{cal} \mathrm{BC} \\
551(40.3 \%)-429 \mathrm{cal} \mathrm{BC}\end{array}$ & $\begin{array}{l}755(24.9 \%)-680 \mathrm{cal} \mathrm{BC} \\
671(15.3 \%)-607 \mathrm{cal} \mathrm{BC} \\
597(55.2 \%)-409 \mathrm{cal} \mathrm{BC}\end{array}$ \\
\hline 6 & $\mathrm{SPb}-2807$ & $2667 \pm 40$ & $\begin{array}{l}891(7.5 \%)-880 \mathrm{cal} \mathrm{BC} \\
845(60.7 \%)-799 \mathrm{cal} \mathrm{BC}\end{array}$ & $901(95.4 \%)-795$ cal BC \\
\hline 7 & SPb-2808 & $9257 \pm 100$ & $8606(68.2 \%)-8343$ cal BC & $8735(95.4 \%)-8286$ cal BC \\
\hline
\end{tabular}

remains made it possible to reconsider the age of the site*. Seven age intervals were obtained (see Table).

The dates generated on samples 1, 2, 4, and 5 do not allow us to determine correctly the chronology of the formation of the culture-bearing layer. However, these dates provide grounds to attribute the More-Yu II site to the early Iron Age. The period of the site's existence was determined by extreme age assessments (by $\pm 2 \sigma)$ as the 6 th century BC to the 2 nd century AD. Given such a long chronological interval, it can be assumed that the site was inhabited recurrently. The set of non-ceramic artifacts, whose common lower chronological boundary dates back to the range from the late 1st millennium $\mathrm{BC}$ to the turn of the eras (early 1st millennium AD), does not contradict the chronological attribution proposed above.

It does not seem possible to explain the discrepancies between the radiocarbon dates of samples 3, 6, and 7 and the abovementioned dates. These dates are not applicable to the site's age assessment primarily because they do not conform to the available archaeological materials. The typological homogeneity of the majority of the recovered ceramics could hardly remain intact throughout many centuries, beginning with the 10th to 8th centuries BC (sample 6) till the 7th to 8th centuries AD (sample 3), as well as the Early Mesolithic period (sample 7).

No direct parallels to the More-Yu ceramic complex have been reported from areas beyond the tundra region

* The analysis was executed in the Isotope Center of the Herzen State Pedagogical University of Russia in St. Petersburg. in the northeastern Europe. We believe that according to such features as the mineral admixture in the paste, the thickened edge, and the pit-comb-cannelure ornamentation style, the More-Yu complex shows similarity to the pottery from the Bolshezemelskaya tundra sites dating to the second half of the 1 st millennium $\mathrm{AD}$ to the early $2 \mathrm{nd}$ millennium $\mathrm{AD}$ (for example, Khutiyunkose and Komatyvis (Murygin, 1992)), and from some sites on the Yamal Peninsula (Brusnitsyna, Oshepkov, 2000: Pl. I, fig. 30, 1, 2; 31, 2, 3; Zeleny Yar..., 2005; Lashuk, 1968: Fig. 2; Morozov, 2003; Plekhanov, 2013: 158-160, fig. 2; "Ushedshie v kholmy...", 1998: 36-37, fig. 20; Chernetsov, 1935: Pl. II, 1-21; 1953: Fig. 6; 1957: Pl. XXV). The parallels in the vessels' shapes and ornamentation patterns were noted with the early pottery from the Northern CisUrals, as well as the medieval pit-comb-fluted ceramics from the Lower $\mathrm{Ob}$ and the Polui River (the settlement of Ust-Vasyegan-1; archaeological sites cluster at Zeleny Yar) (Zeleny Yar..., 2005; Chikunova, 2017: 155, fig. 1); approximately $250 \mathrm{~km}$ up the $\mathrm{Ob}$ from the abovementioned sites (the settlement of Peregrebnoye-4) (Morozov, 2003), and others. Absolute parallels to the Late Bolshezemelskaya and Yamal (Tiutei-Sale type) ceramics have been reported from the vast region reaching the western coast of the Gyda Peninsula (Skochina, Enshin, 2017: 41, fig. 1, 2). Even given the incompleteness and insufficient equivalence of the pottery from the Ob-Yamal archaeological cultures, it could hardly be denied that the set of main features of the More-Yu type ceramics beyond the northeasternmost 
European tundra zone is represented only in the pottery from the West Siberian sites of the Iron Age, and the cannelure feature is noted in even earlier complexes*.

Notably, cannelures, as one of the most significant features in the ornamentation of Belshezemelskaya ceramics, were recorded in the Early Iron Age cultures of the northwestern Russia: Late Beloye More, Late Kargopol, and Luukonsaari. The Karelian archaeologists regard cannelures exclusively as a chronological feature marking links with the Glyadenovo antiques of the Pechora-Vychegda region (Zhulnikov, 2005: 38).

The homogenous ceramic complex of More-Yu II contains vessels that most likely originated in TransUrals. These include vessels of group III, with pits on the interior surface close to the rim (punched nodes) (see Fig. 3, 29-33). Pottery of this type is scarce in collections from the Iron Age sites in the Pechora and Vychegda taiga zone, and in the northeasternmost tundra zone of Europe. Such an ornamental pattern, widespread in the West Siberian cultures, can be regarded as a borrowed feature of the Trans-Urals tradition in the ceramics of the Pechora basin in Cis-Urals. The vessel with protrusions ("ears") on the rim (group VII; see Fig. 3, 19) is atypical for More-Yu II, and in general for the Iron Age of the northeastern Europe. Similar vessels were found in the damaged tundra sites of Korotaikha 268/59, Korotaikha 292/82, Padimei-vis 227/18, and Padimei-vis 240/31 (Chernov, 1985: Pl. 16, 13, 14). In the taiga zone, these are represented in the Ananyino complex at the site of Shoinaty II (Korolev, 1997: Fig. 18, 13) and in burial 1 of the Early Anayino Period (the 8th to 7th centuries BC) at the same site (Korolev, 2002: 35, 36, fig. 34, 7). The artifacts collected by V.I. Kanivets in 1967 included a pot-shaped ceramic vessel with a ring-shaped handle at the rim, with three button-like protrusions (Murygin, 1992: Fig. 48, 1). A miniature bronze imitation of a coneshaped cauldron with trihedral handles and a marked tray was found at the Kheibidya-Pedar sanctuary (Ibid.: Fig. 21, 42). It cannot be ruled out that these items were imitations of the metal cauldrons of nomadic tribes of the Eurasian steppes of the Scythian-Sarmatian Period. These can be regarded as the evidence of penetration of features of the southern cultures into the Subarctic European zone.

The aging of the More-Yu finds and, consequently, of the More-Yu cultural type in general, affects various issues relating to the Iron Age archaeology of the northeastern Europe, and possibly also contiguous regions. It seems reasonable to touch upon the concept of the formation of certain cultural types in the southern regions of the Pechora basin (Murygin, 1992).

*The issue of the origin of the fluted ornamentation in the West Siberian ceramics is still debatable; see, e.g., (Zykov, 2012: 55-58).
At the turn of the Iron Age and the Middle Ages, in the areas of the boreal belt in the northeastern Europe, new cultural types were formed owing to the active contacts between the local populations and the newcomers (Murygin, 2013). The changes occurring in the northeastern periphery of the Glyadenovo cultural area (Pechora basin) were indicated by the formation, by the mid-1st millennium AD, of the Bichevnik cultural type on the basis of the Pidzh culture (one of the cultures belonging to the Glyadenovo cultural community). One of the authors believes that population groups from the Bolshezemelskaya tundra also participated in the initial stage of development of the Bichevnik cultural type (Murygin, 1992). The tundra tribes migrated to the regions southwards from the Arctic Circle because of the climate's cooling during the Subboreal to Subatlantic transition period.

Critical to the understanding of this phase of the Iron Age in the northeastern Europe is that the infiltration of foreign population into the area of the Glyadenovo culture in the Pechora basin (and possibly Vychegda basin) was a long-term process (probably starting from the last quarter of the 1st millennium BC), taking place only in one, albeit declining, forest zone landscape. The Glyadenovo ceramics with cannelures occurred in Pechora sites as early as in the late 3 rd to 2 nd centuries BC [Vaskul, 1997: 379], which time can be regarded as the start of the migration-process.

The proposed cultural-historical pattern and its substantiation have one weak point. The Arctic component of the Bichevnik cultural type should be older than the type itself. This was not consistent with the original date, according to which the Arctic component was roughly synchronous with the Bichevnik relics. The results of radiocarbon analysis of the cultural remains have eliminated this contradiction and supported the proposed pattern of culture genesis of the Bichevnik population in the Pechora taiga area.

\section{Conclusions}

More-Yu II is currently the earliest and most thoroughly studied archaeological one-layer site attributed to the aboriginal culture of the Subarctic type of the Iron Age in the northeasternmost part of European Russia. The ${ }^{14} \mathrm{C}$-dating results attribute the site to the Early Iron Age. Earlier, no reliable evidence on the existence of local population settlements in the European tundra belt during that period of time had been available. Study of the archaezoological assemblage* showed that the subsistence strategy of the inhabitants of More-Yu II was

\footnotetext{
*Archaezoological collection is kept on the Museum of the IPAE UB RAS.
} 
reindeer (Rangifer tarandus) hunting. In the assemblage of mammal bones, the species was identified for 3496 bones ( $67.6 \%$ of the total number), among which $97.0 \%$ were reindeer bones. Of the total of 142 identified mammal individuals, 132 were defined as reindeer. The majority of individuals were mature when butcheredolder than 5 years of age $(77 \%)$. The time of butchering can be determined roughly. The hunting season was identified only for three individuals: it lasted from late fall to early spring. Because no bird remains were found at the site, but there are some fur-bearing animal bonessable (Martes zibellina) and Polar fox (Alopex lagopus) it can be suggested that the animal bone assemblages were accumulated in winter. The site was apparently a seasonal camp for reindeer hunters, used mostly during winter time.

Study of the archaeological sources allowed us to identify the Early Iron Age materials in the medieval Bolshezemelskaya tundra ceramic complexes, including the ceramic-types of More-Yu, Khutiyunkose, and Komatyvis (Murygin, 1992). Such Early Iron Age materials represent the Arctic component of the Bichevnik cultural type. These people of the Subarctic zone, thanks to centuries-long infiltration southwards from the North Circle, had dramatically changed by the mid-1st millennium AD the traditional pottery produced by the Finno-Permic (Glyadenovo) population of the taiga part of the Pechora basin.

Gradual out-migration of part of the Arctic population to the more southern areas of the Pechora basin was due to deterioration of climatic conditions in northeastern Europe during the early Subatlantic period. Notably, such climatic changes have a strong negative impact on subsistence strategies in the Arctic zone, and cause an increase in migration mobility of living beings as a form of adaptation to environmental variability (Krupnik, 1989). According to the results of palynological analysis, the period of formation of anthropogenic finds, coinciding with the early stage (zone SA-1) of the Subatlantic period, was characterized by the unstable temperature regime. Spore and pollen assemblages, based on the palynological data, identified in the culture-bearing soil horizon, show both relatively warm and humid conditions, and climate deterioration at and around the site.

These data are consistent with the known scheme of the zonal division of the Holocene in the northeastern part of European Russia. Within the boundaries of the Subatlantic period, the time of use of the More-Yu II site almost corresponds to the Early Subatlantic, which accounts for the continuing deterioration of the climate. Among other consequences, there was a shift of landscape zones in the meridional direction, and expansion of the tundra zone with the shift of the forest boundary by $150 \mathrm{~km}$ southwards from the modern one (Nikiforova, 1982: 156, 160). This basic position is supported in more recent works on paleoclimatology. The publications by L.V. Filimonova and V.A. Klimanov (2005), and A.G. Isachenko (2013) justified the provision that at the early stage (zone SA-1, 2500-1800 BP), the Subatlantic climatic conditions were more severe than was previously believed (Nikiforova, 1982). Throughout its duration, the temperature regime changed several times. The Early Subatlantic began with strong cooling circa $2500 \mathrm{BP}$, which fact has been recorded all over the territory of Russia. Then, there were two warm periods (about 2300 and $2000 \mathrm{BP}$ ), separated by a period of cooling with a peak around 2200-2100 BP.

The genesis of the Iron Age Bolshezemelskaya ceramics of the Subarctic type is not clear. Cultures of the Late Bronze to Early Iron Ages of the Subarctic Pechora area, representing the local basis of subsequent cultural formations in this territory, were not reflected in the archaeological sources, nor were their materials identified in the available collections. The issue of the development of the cannelure ceramic complex in the Subarctic European area is still debatable: this was either due to large-scale changes in the $\mathrm{Ob}$ Basin in the 1 st millennium $\mathrm{BC}$ to early 1 st millennium $\mathrm{AD}$, or to the convergent development in line with indigenous traditions.

Any reliable evidence on the direct correlation of the circumpolar Subarctic Cis-Urals culture with any of the Trans-Urals Iron Age cultures has not been established so far. However, the noted typological affinity of the Ob-Yamal pottery to the ceramics of Bolshezemelskaya tundra makes it possible to outline roughly the eastern and western boundaries of the dispersal area of similar traditions of ornamentation. We suggest that during the range from the second stage of the Early Iron Age to the turn of 1st to 2nd millennium $\mathrm{AD}$, a vast territory of Subarctic and Arctic regions of the Lower Ob, Yamal, and Bolshezemelskaya tundra was populated by closely related tribes. Among them, the North European group had common origin and traditions with the West-Siberian (Ancient Ugrian, Ancient Samoyedic, and UgricSamoyedic) ethno-cultural area.

\section{Acknowledgements}

The study was performed under R\&D Project No. 0417-20140007, entitled "Settlement and Development of the Circumpolar Zone of the Northeastern Part of the East European Plain and the Urals According to the Archaeological Evidence"; R\&D Project No. AAAA-A17-117121140081-7 "Bio-geological Facts and Stratigraphy of the Phanerozoic in the Subarctic Zone of the Barents Sea Region, the Timan Ridge, and the Western Face of the Urals"; and the multidisciplinary basic research program of the Ural Branch of the Russian Academy of Sciences for 2018-2020, entitled "Ethno-Cultural Processes in the Circumpolar Zone of the Northeastern Europe in the Iron 
Age and Medieval Period" (Project No. 18-6-6-30), as well as supported by the Russian Foundation for Basic Research (Project No. 18-04-00982).

\section{References}

\section{Alekseeva E.M. 1975}

Antichniye busy Severnogo Prichernomorya. Moscow: Nauka. (SAI; iss. G1-12).

Baryshev I.B. 2011

Yazycheskiye svyatilishcha ostrova Vaigach. Moscow: Institut Naslediya.

\section{Brusnitsyna A.G., Oschepkov K.A. 2000}

Pamyatniki arkheologii Srednego Yamala (levoberezhye nizhnego techeniya r. Yuribey). In Drevnosti Yamala, iss. 1. Yekaterinburg, Salekhard: UrO RAN, pp. 79-111.

\section{Chernetsov V.N. 1935}

Drevnyaya primorskaya kultura na poluostrove Yamal. Sovetskaya etnographiya, No. 4/5: 109-133.

Chernetsov V.N. 1953

Drevnyaya istoriya Nizhnego Priobya. In Drevnyaya istoriya Nizhnego Priobya. Moscow: Nauka, pp. 7-71. (MIA; No. 35).

Chernetsov V.N. 1957

Nizhneye Priobye v I tysacheletii n.e. In Kultura drevnikh plemen Priuralya i Zapadnoy Sibiri. Moscow: Nauka, pp. 136245. (MIA; No. 58).

Chernov G.A. 1985

Atlas arkheologicheskikh pamyatnikov Bolshezemelskoy tundry. Moscow: Nauka.

\section{Chikunova I.Y. 2017}

Srednevekoviy keramicheskiy kompleks gorodishcha Ust-Vasiyogan 1 (2013-2015 gg.). In I Mezhdunar. konf. "Arkheologiya Arktiki" (19-22 noyabrya, Salekhard): Tezisy dokl. Yekaterinburg: pp. 155-158.

Edovin A.G. 2007

Otchet o razvedke arkheologicheskogo otryada AOKM na territorii Arkhangelskoy oblasti i Nenetskogo avtonomnogo okruga v 2007 g. Arkhiv AOKM. F. 3, Inv. 1.

\section{Filimonova L.V., Klimanov V.A. 2005}

Izmeneniye kolichestvennykh pokazateley paleoklimata v srednetayezhnoy podzone Karelii za posledniye 11000 let. In Trudy Karel. nauch. tsentra RAN, iss. 8. Petrozavodsk: pp. 112-120.

Isachenko A.G. 2013

Paleogeograficheskiye i etnoistoricheskiye predposylki istoricheskoy geografii oblasti poslednego oledeneniya Russkoy ravniny. St. Petersburg: Nauka, pp. 1-17. (Izv. RGO; vol. 145, iss. 3).

\section{Ivanov V.A. 1984}

Vooruzheniye i voyennoye delo finno-ugrov Priuralya $\mathrm{v}$ epokhu rannego zheleza (I tys. do n.e. - pervaya polovina I tys. n.e.). Moscow: Nauka.

Kanivets V.I. 1967

Otchet o rabote I Pechorskogo arkheologicheskogo otryada v 1967 g. Arkhiv Komi NTs UrO RAN. F. 1, Inv. 13, D. 161, 162.

\section{Khlobystin L.P. 1991}

Kultoviye pamyatniki ostrova Vaigach. In Pamyatniki Arkhangelskogo Severa. Arkhangelsk: Severo-Zapad. kn. izd., pp. 23-38.

\section{Khlobystin L.P. 1993}

Svyatilishcha Vaigacha. In AD POLUS: Arkheologicheskiye izyskaniya, iss. 10. St. Petersburg: Farn, pp. 15-18.

Korolev K.S. 1997

Naseleniye sredney Vychegdy v drevnosti i srednevekovye. Yekaterinburg: UrO RAN.

Korolev K.S. 2002

Ugdymskiy arkheologicheskiy kompleks na sredney Vychegde (epokha zheleza). Syktyvkar: Izd. Komi NTs UrO RAN.

Krupnik I.I. 1989

Arkticheskaya etnoekologiya. Moscow: Nauka.

Lashuk L.P. 1968

Sirtya - drevniye obitateli subarktiki. In Problemy antropologii $i$ istoricheskoy etnografii Azii. Moscow: Nauka, pp. 178-193.

\section{Medvedev A.F. 1966}

Ruchnoye metatelnoye oruzhiye (luk i strely, samostrel) VIII-XIV vv. Moscow: Nauka. (SAI; iss. E1-36).

\section{Morozov V.M. 2003}

O dvukh keramicheskikh kompleksakh Nizhnego Priobya, 2003. Arkheologiya Yamala. GKU YANAO "Tsentr izucheniya Arktiki”. URL: http://yamalarchaeology.ru/index.php/texts/ archeol/98-morozov-v-m-2003 (Accessed December 6, 2018).

\section{Murygin A.M. 1990}

Poseleniye More-yu v Bolshezemelskoy tundre. KSIA, No. 200: 60-66.

\section{Murygin A.M. 1992}

Pechorskoye Priuralye: Epokha srednevekovya. Moscow: Nauka.

Murygin A.M. 1997

Pamyatniki pozdnego zheleznogo veka lesnoy i tundrovoy polosy Pechorskogo Priuralya. In Arkheologia Respubliki Komi. Moscow: DiK, pp. 478-560.

Murygin A.M. 2013

Migratsii kak sposob vzaimodeistviya naseleniya krainego severo-vostoka yevropeiskoy chasti Rossii v rannem srednevekovye. Vestnik Tomskogo gosudarstvennogo universiteta. Istoriya, No. 3 (23): 254-258.

\section{Nikiforova L.D. 1982}

Dinamika landshaftnykh zon golotsena severo-vostoka Yevropeiskoy chasti SSSR. In Razvitiye prirody territorii SSSR v pozdnem pleistotsene i golotsene. Moscow: Nauka, pp. 154-162.

\section{Plekhanov A.V. 2013}

Yamalskaya Arktika v epokhu srednevekovya: Pamyatniki v zone tipichnoy tundry. In Arkheologia Severa Rossii ot epokhi zheleza do Rossiyskoy imperii: Materialy Vseros. nauch. arkheol. konf. (Surgut, 1-4 okt. 2013 g.). Yekaterinburg, Surgut: pp. 157-165.

\section{Skochina S.N., Enshin D.N. 2017}

Arkheologicheskiye issledovaniya na severo-zapadnom poberezhye Gydanskogo p-ova. In I Mezhdunar. konf. "Arkheologiya Arktiki" (19-22 noyabrya, Salekhard): Tezisy dokl. Yekaterinburg: pp. 40-43.

\section{Soloviev A.I. 1987}

Voyennoye delo korennogo naseleniya Zapadnoy Sibiri: Epokha srednevekovya. Novosibirsk: Nauka.

Turkina T.Y. 2015

Poseleniye Bichevnik I na sredney Pechore. Pervobytniye i srednevekoviye drevnosti Yevropeiskogo Severo-Vostoka. 
Syktyvkar: IYALI Komi NTs UrO RAN, pp. 80-88. (MAESV; iss. 19).

\section{"Ushedshie v kholmy". 1998}

Kultura naseleniya poberezhiy Severo-Zapadnogo Yamala v zheleznom veke. Arkheologiya Yamala. GKU YANAO "Tsentr izucheniya Arktiki". URL: http://www.yamalarchaeology. ru/index.php/texts/archeol/100-ushedshie-v-kholmy-1998 (Accessed December 6, 2018).

Vaskul I.O. 1997

Pamyatniki glyadenovskoy kulturnoy obshchnosti. In Arkheologiya Respubliki Komi. Moscow: DiK, pp. 349-399. Zeleny Yar: Arkheologicheskiy kompleks epokhi srednevekovya v Severnom Priobye. 2005

N.V. Fedorova (ed.). Yekaterinburg, Salekhard: UrO RAN.

\section{Zhulnikov A.M. 2005}

Poseleniya epokhi rannego metalla Yugo-Zapadnogo Pribelomorya. Petrozavodsk: Paritet.

Zykov A.P. 2012

Barsova Gora: Ocherki arkheologii Surgutskogo Priobya. Srednevekovye i novoye vremya. Yekaterinburg: Ural. rabochiy. 